\title{
Occurrence of Bothriocephalus acheilognathi in cyprinid fish from three lakes in the flood plain of the Yangtze River, China
}

\author{
P. Nie*, G. T. Wang, W. J. Yao, Y. A. Zhang, Q. Gao \\ State Key Laboratory of Freshwater Ecology and Biotechnology, and Laboratory of Fish Diseases, Institute of Hydrobiology, \\ Chinese Academy of Sciences, Wuhan 430072, Hubei Province, PR China
}

\begin{abstract}
Cyprinid fish, Hemiculter leucisculus, Cultrichthys erythropterus and Culter dabryi, were sampled from Liangzi, Honghu and Tangxun lakes in the flood plain of the Yangtze River. The cestode Bothriocephalus acheilognathi Yamaguti, 1934 was found in the 3 lakes, but $C$. erythropterus sampled from Liangzi lake was found uninfected due probably to the small sample size. Findings of the cestode in the 3 lakes represent the first record of the parasite in the flood plain of the Yangtze River, indicating that B. acheilognathi may be distributed much wider in China than previously recognized.
\end{abstract}

KEY WORDS: Bothriocephalus acheilognathi - Hemiculter leucisculus - Cultrichthys erythropterus . Culter dabryi Yangtze River flood plain lakes · China

During a study of diseases of grass carp Ctenopharyngodon idellus C. \& V., in Guangdong Province of south China, a pathogenic cestode was found and named Bothriocephalus gowkongensis Yeh, 1955 (Liao \& Shih 1956). This parasite has subsequently caused worldwide concern, due to its pathogenecity and distribution. The parasite, now known as $B$. acheilognathi Yamaguti, 1934, is considered to have been introduced from China initially to East Europe and thence to other parts of the world (Hoole 1994). Despite its wide distribution and the large number of fish species reported as definitive hosts (Hoole 1994), the cestode was considered to have a rather limited distribution in China (Pan et al. 1990, Nie 1995). Indeed, the cestode has not hitherto been found in carp Cyprinus carpio L. in lakes in the flood plain of the Yangtze River (Nie et al. 1999). However, during further investigations into the fish parasites in lakes in the flood plain, B. acheilognathi was recorded in 3 species of cyprinid fish and in 3 lakes. The occurrence of this cestode in these lakes is therefore reported in this paper.

•E-mail: pinnie@ihb.ac.cn
A large number of lakes of various sizes are distributed in the flood plain of the Yangtze River (Chen \& $\mathrm{Xu}$ 1995). In the present study, the 3 lakes sampled (Table 1) are located in Hubei province. All fish were gill-netted, and transferred to the laboratory on the same day. The fork length and body weight of each fish were measured. Intestines of the fish were removed and examined under a microscope. Helminths found were identified alive and carminestained.

The cyprinids Hemiculter leucisculus (Basilewsky), Cultrichthys erythropterus (Basilewsky) and Culter dabryi (Bleeker) were sampled and they all harboured the cestode Bothriocephalus acheilognathi (Table 2). Prevalence and abundance of the cestode was higher in $C$. erythropterus than in $H$. leucisculus in both Honghu and Tangxun lakes. The absence of the cestode from $C$. erythropterus in Liangzi lake and the higher infection level in C. dabryi in Tangxun lake may be explained by the small sample sizes of each fish species.

Bothriocephalus acheilognathi has been recorded in Hemiculter leucisculus in highland lakes in southwest China (Nie 1995), whereas Cultrichthys erythropterus and Culter dabryi are new final hosts of the cestode.

Since Bothriocephalus acheilognathi has not been found in Cyprinus carpio and grass carp, the 2 major definitive hosts of the cestode worldwide, nor in many other species of fish in lakes in the flood plain of the

Table 1. Features of the 3 lakes in the flood plain of the lower and middle reaches of the Yangtze River, China

\begin{tabular}{|lccc|}
\hline Feature & Liangzi & Honghu & Tangxun \\
\hline Longitude & $114^{\circ} 21^{\prime}-39^{\prime} \mathrm{E}$ & $113^{\circ} 11^{\prime}-28^{\prime} \mathrm{E}$ & $114^{\circ} 19^{\prime}-29^{\prime} \mathrm{E}$ \\
Latitude & $30^{\circ} 05^{\prime}-18^{\prime} \mathrm{N}$ & $29^{\circ} 38^{\prime}-59^{\prime} \mathrm{N}$ & $30^{\circ} 23^{\prime}-29^{\prime} \mathrm{N}$ \\
Area $\left(\mathrm{km}^{2}\right)$ & 304.3 & 344.4 & 36.6 \\
$\begin{array}{l}\text { Depth }(\mathrm{m}) \\
\text { (maximum, average) }\end{array}$ & $6.2,4.16$ & $2.2,1.91$ & $2.4,1.85$ \\
\hline
\end{tabular}


Table 2. Prevalence $(\mathrm{P}, \%)$ and abundance $(\mathrm{A}$, mean $\pm \mathrm{SD})$ of the cestode Bothriocephalus acheilognathi in Hemiculter leucisculus, Cultrichthys erythropterus and Culter dabryi from 3 lakes in the flood plain of the Yangtze River, China. N: sample size; FL: fish fork length in $\mathrm{cm}$ (mean $\pm \mathrm{SD}) ;-$ : no data obtained

\begin{tabular}{|c|c|c|c|c|c|c|c|c|c|c|c|c|}
\hline \multirow[t]{2}{*}{ Host species } & \multicolumn{4}{|c|}{ Liangzi } & \multicolumn{4}{|c|}{ Honghu } & \multicolumn{4}{|c|}{ Tangxun } \\
\hline & $\mathrm{N}$ & $\mathrm{FL}^{\mathrm{a}}$ & $P$ & A & $\mathrm{N}$ & FL & $\mathrm{P}$ & A & $\mathrm{N}$ & FL & $\mathrm{P}$ & A \\
\hline H. leucisculus & 448 & $\begin{array}{r}9.15 \\
\pm 1.08\end{array}$ & 0.89 & $\begin{array}{ll} & 0.018 \\
\pm & 0.21\end{array}$ & 230 & $\begin{array}{r}9.99 \\
\pm 0.91\end{array}$ & 0.43 & $\begin{array}{c}0.004 \\
\pm 0.07\end{array}$ & 433 & $\begin{array}{r}9.13 \\
\pm 0.94\end{array}$ & 2.3 & 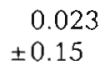 \\
\hline C. erythropterus & 10 & $\begin{array}{l}12.93 \\
\pm 1.28\end{array}$ & 0 & 0 & 124 & $\begin{array}{l}11.47 \\
\pm 1.10\end{array}$ & 0.81 & $\begin{array}{l}0.016 \\
\pm 0.18\end{array}$ & 63 & $\begin{array}{r}9.43 \\
\pm 1.05\end{array}$ & 23.8 & $\begin{array}{r}0.27 \\
\pm 0.54\end{array}$ \\
\hline C. dabryi & - & & & & - & & & & 3 & 10.00 & 33.3 & $\begin{array}{r}1.33 \\
\pm 2.31\end{array}$ \\
\hline
\end{tabular}

Yangtze River (Pan et al. 1990, Nie ct al. 1999), it was generally believed that $B$. acheilognathi did not exist in lakes of the flood plain. Findings of the parasite in the 3 lakes may indicate that the number of species of definitive host and geographical distribution of the cestode are wider than previously recognized in China. However, further investigations should be carried out to clarify the epidemiology of the cestode in China and be extended to encompass the study of genetic variations of the cestode populations in different species of definitive hosts.

Acknowledgements. We are very grateful for a research grant from the Systematic and Evolutionary Biology Programme of the Chinese Academy of Sciences. Many anonymous fishermen were involved in the sampling effort, to whom our sincere thanks are due.

Editorial responsibility: Wolfgang Körting,

Hannover, Germany

\section{LITERATURI CITED}

Chen YY, Xu YG (1995) Hydrobiology and resources exploitation in Honghu Lake. Science Press, Beijing

Hoole D (1994) Tapeworm infections in fish: past and future problems. In: Pike AW, Lewis JW (eds) Parasitic diseases of fish. Samara Publishing Ltd, Tresaith

Liao H. Shih L (1956) Contribution to the biology and control of Bothriocephalus gowkongensis Yeh, a tapeworm parasitic in the young grass carp (Ctenopharyngodon idellus C. \& V.). Acta Hydrobiol Sin 2:129-185

Nie P (1995) Communities of intestinal helminths of carp. Cyprinus carpio, in highland lakes in Yunnan province of southwest China. Acta Parasitol 40:148-151

Nie P, Yao WJ, Gao Q, Wang GT, Zhang YA (1999) Diversity of intestinal helminth communities of carp from six lakes in the flood plain of the Yangtze River, China. J Fish Biol $54: 171-180$

Pan JH, Zhang JY, Li ZC (1990) Fish parasitology. Science Press, Beijing

Submitted: January 3, 2000; Accepted: February 29, 2000

Proofs received from author(s): April 17, 2000 